\title{
Interference of nutrients with fungicide activity against Septoria nodorum on wheat leaves
}

\author{
A. J. DIK, ${ }^{*} \dagger$ N. J. FOKKEMA $\ddagger$ and J. A. VAN PELT* \\ * Department of Plant Ecology and Evolutionary Biology, Section of Plant Pathology, University of \\ Utrecht, Javalaan 20,3742 CP Baarn, The Netherlands \\ $\dagger$ Department of Theoretical Production Ecology, Wageningen Agricultural University, PO Box 430, \\ 6700 AK Wageningen, The Netherlands \\ $\ddagger$ Research Institute for Plant Protection, PO Box 9060, $6700 \mathrm{GW}$ Wageningen, The Netherlands
}

The effect of nutrients on reduction of the germination and mycelial growth of Septoria nodorum by the fungicides propiconazole, fenpropimorph and prochloraz, and on the reduction of S. nodorum infection by prochloraz, was tested on wheat plants in a controlled environment. The nutrients tested were aphid honeydew, sucrose, a mixture of amino acids and combinations of sucrose with yeast extract and amino acids, all in different concentrations. All nutrients could stimulate $S$. nodorum infection in combination with the tested prochloraz concentrations (4.5-45 $\mathrm{mg}$ a.i./l), but amino acids did not significantly stimulate infection in the fungicide-free treatments. The stimulating effect of the nutrients was generally stronger with higher nutrient/fungicide ratios. Aphid honeydew had more effect than its main components sucrose and amino acids separately. Antagonism between nutrients and prochloraz was determined with the Colby method and from dose-response curves by comparing $\mathrm{ED}_{50} \mathrm{~S}$ and drawing antagonism isoboles. Aphid honeydew, sucrose and amino acids caused an up to 10 -fold increase of the $\mathrm{ED}_{50}$ and can be considered antagonistic to prochloraz.

\section{INTRODUCTION}

The effect of a fungicide on plant pathogens can be influenced by substances mixed with the chemical or naturally present in the environment of the pathogen. Such interaction is called synergism when the effect of the fungicide is enhanced and antagonism when it is decreased. When the toxicity, measured, for example as $\mathrm{ED}_{50}$, is not changed, the effect of the chemicals is called additional (Tammes, 1964). The effect of substances that are commonly available to pathogens on the effectiveness of fungicides is not yet well documented.

Field experiments by Rabbinge et al. (1984) demonstrated that the control of "phyllosphere fungi on wheat leaves by captafol was significantly reduced in the presence of aphid honeydew. As aphid honeydew has been shown to enhance spore germination and germ-tube growth of Cochliobolus sativus and lesion development of both Septorianodorum and Cochliobolus sativus (Fokkema et al., 1983), we became interested in the role of nutrients in the performance of fungicides. The aim of the work pre- sented here was to investigate whether aphid honeydew is antagonistic to fungicides that are commonly used in cereals and, if so, to establish which of the main components of honeydew causes the effect.

Aphid honeydew produced by Sitobion avenae on wheat consists of carbohydrates (c. $98 \%$ of the dry matter) and of a mixture of many amino acids (c. 2\%) (Rossing \& Van de Wiel, 1990). The interaction of a range of amino acids and carbohydrates with the effect of different fungicides on various necrotrophic pathogens such as Alternaria spp., Rhizoctonia spp., Fusarium spp., Aspergillus spp. and Pythitum spp. has been described. Both amino acids and carbohydrates can be either synergistic or antagonistic to fungicides (Grover \& Kumar, 1965; Grover \& Sidhu, 1965; Beynon \& Brown, 1969; Chopra \& Jhooty, 1974; Jhooty \& Bains, 1976; Kataria \& Grover, 1978). Richardson (1966), Beynon \& Brown (1969), Dunn et al. (1971) and Chopra \& Jhooty (1974) showed that leaf, root and spore exudates, containing both carbohydrates and amino acids, can all be antagonistic to a range of fungicides. Practically all these interactions, however, are 
studied under in vitro conditions, measuring germination and mycelial growth. The effect on infection and the importance of these interactions in agricultural practice is unknown.

The experiments described here were conducted on spring wheat plants in a controlled environment with the necrotrophic fungus Septoria nodorum (teleomorph: Leptosphaeria nodorum), causal agent of glume blotch of wheat, as the test pathogen. The first experiments were carried out to assess the effect of a mixture of sucrose and yeast extract, which resembles the effect of aphid honeydew on necrotrophic pathogens (Fokkema et al., 1983), on the activity of different fungicides. Subsequently, prochloraz was used as the test fungicide and the influence of composition and concentration of different nutrients, including aphid honeydew, on fungicide effectiveness was investigated.

\section{MATERIAL AND METHODS}

\section{Plants}

Spring wheat, Triticum aestivum $\mathrm{cv}$. Minaret, was sown in potting soil (Triomf nr. 17, TRIO B.V.) in pots $20 \times 20 \mathrm{~cm}$ ( 25 seeds per pot) and grown in the greenhouse at $18-25^{\circ} \mathrm{C}$ with additional light during autumn and winter. If necessary, mildew infection, caused by Erysiphe graminis f.sp. tritici, was suppressed by spraying with ethirimol (Milgo E, ICI) with avoidance of the flag leaves. Aphids, if present, were eliminated with pirimicarb (Pirimor, ICI), which does not affect Septoria nodorum. The flag leaves of the plants were used at growth stage DC 50-60 (Zadoks et al., 1974).

\section{Pathogen}

Isolate WCS-F35 of the pathogen S. nodorum was grown on oatmeal agar plates at $18^{\circ} \mathrm{C}$ and under $12 \mathrm{~h}$ near-UV light per day. After incubation for 10-15 days, a conidial suspension was made in sterile Tween 80 solution $(0.01 \%)$ by cautiously scraping the conidia from the plates. The suspension was filtered through glass wool to remove mycelium and pieces of agar and was diluted in sterile Tween 80 solution to a concentration of $1-$ $5 \times 10^{6}$ spores per $\mathrm{ml}$. The conidial suspension was not washed, as washing the suspension did not influence germination or germ-tube growth of the spores, so it is unlikely that nutrients from the agar or cirrhus extract interfered with the experiments (A. J. Dik, unpublished data).

\section{Fungicides}

The fungicides propiconazole (Tilt 250 E.C., $250 \mathrm{~g}$ active ingredient $/ 1$, Ligtermoet Chemie B.V.), fenpropimorph (Corbel, $750 \mathrm{~g}$ active ingredient/1, BASF) and prochloraz (Sportak, $450 \mathrm{~g}$ active ingredient/1, Schering AAgrunol) were used, all belonging to the group of the ergosterol biosynthesis inhibitors (EBIs) and recommended for the control of various cereal-leaf diseases including glume blotch. Fungicide concentrations for all experiments are given in Table 1 .

\section{Nutrients}

Sucrose (Merck) was used in different concentrations and was combined in the first experiments with yeast extract (Difco, $5 \mathrm{~g} / \mathrm{l}$ ), because the effect of this mixture on $S$. nodorum resembles that of aphid honeydew (Fokkema et al., 1983).

In three experiments, a mixture of the following amino acids was used: alanine $(0 \cdot 12 \mathrm{~g} / \mathrm{l})$, asparagine $(0.25 \mathrm{~g} / \mathrm{l})$, glutamine $(0.20 \mathrm{~g} / \mathrm{l})$, glycine $(0.07$ $\mathrm{g} / \mathrm{l})$, histidine $(0.31 \mathrm{~g} / 1)$, isoleucine $(0.14 \mathrm{~g} / \mathrm{l})$, leucine $(0.23 \mathrm{~g} / \mathrm{l})$, lysine $(0.08 \mathrm{~g} / \mathrm{l})$, proline $(0.25$ $\mathrm{g} / \mathrm{l})$, phenylalanine $(0.20 \mathrm{~g} / \mathrm{l})$, threonine $(0.84 \mathrm{~g} / 1)$, tyrosine $(0.23 \mathrm{~g} / \mathrm{l})$ and valine $(0.25 \mathrm{~g} / \mathrm{l})(\mathrm{BDH}$, Merck, Sigma). This composition is the same as determined by HPLC in honeydew of the aphid Sitobion avenae reared for 3 days in a controlled environment on field-grown winter wheat plants cv. Arminda (Rossing \& Van de Wiel, 1990), based on $15 \%$ dry matter. This mixture contains $3.17 \mathrm{~g}$ amino acids/ 1 and was also used in higher and lower concentrations.

In three experiments aphid honeydew was used. It was collected on glass slides in a growth cabinet in which $S$. avenae was reared on spring wheat plants cv. Minaret. After 3-4 days of exposure in the growth cabinet the glass slides were washed in ultrapure water in an ultrasonic waterbath (Branson) and the washings were freeze dried. The dry weight was assessed and the honeydew was resuspended in ultrapure water and diluted to concentrations of 10,20 and $50 \mathrm{mg}$ honeydew $/ \mathrm{ml}$. Actual concentration of the sugars in the honeydew was established by anthrone reagent, which measures the total amount of carbohydrates (Hewitt, 1958).

Nutrient concentrations for all experiments are given in Table 1. Control leaves were sprayed with nutrients without addition of $S$. nodorum spores to assess a possible effect of the nutrients on the leaves. 
Table 1. Fungicide and nutrient concentrations in all experiments

\begin{tabular}{|c|c|c|c|}
\hline Experiment & Fungicide & $\begin{array}{l}\text { Fungicide } \\
\text { concentration } \\
\text { (mg a.i./l) }\end{array}$ & Nutrients \\
\hline 1 & Propiconazole & $0,12 \cdot 5,25,50$ & 20 g sucrose $/ 1+5 \mathrm{~g} \mathrm{YE} / 1$ \\
\hline 2 & Fenpropimorph & $0,75,150,300$ & $20 \mathrm{~g}$ sucrose $/ 1+5 \mathrm{~g} \mathrm{YE} / 1$ \\
\hline 3 & Prochloraz & $0,4 \cdot 5,11 \cdot 3,22 \cdot 5$ & $20 \mathrm{~g}$ sucrose $/ 1+5 \mathrm{~g} \mathrm{YE} / 1$ \\
\hline 4 & Prochloraz & $0,22 \cdot 5,45$ & 20 g sucrose $/ 1+5$ g YE/1 \\
\hline 5 & Prochloraz & $0,45,135$ & $20 \mathrm{~g}$ sucrose $/ 1+5 \mathrm{~g} \mathrm{YE} / 1$ \\
\hline 6 & Prochloraz & $0,4 \cdot 5,11 \cdot 3,22 \cdot 5,45,135,225$ & $\begin{array}{l}10,20,50,100,150 \mathrm{~g} \\
\mathrm{~S} / 1+5 \mathrm{~g} \mathrm{YE} / 1\end{array}$ \\
\hline 7 & Prochloraz & $0,4 \cdot 5,11 \cdot 3,22 \cdot 5,45$ & $\begin{array}{l}1 \cdot 1,3 \cdot 2,10 \cdot 6 \mathrm{~g} \text { amino acids } / 1 \\
8 \cdot 5,19 \cdot 0,47 \cdot 0 \mathrm{~g} \text { honeydew } / 1\end{array}$ \\
\hline 8 & Prochloraz & $0,4 \cdot 5,11 \cdot 3,22 \cdot 5,45$ & $\begin{array}{l}10,20,50,100 \mathrm{~g} \text { sucrose } / \mathrm{l} \\
3 \cdot 8,7 \cdot 5,18 \cdot 8 \mathrm{~g} \text { honeydew } / 1\end{array}$ \\
\hline 9 & Prochloraz & $0,4 \cdot 5,11 \cdot 3,22 \cdot 5,45$ & $\begin{array}{l}1 \cdot 1,10.6 \mathrm{~g} \text { amino acids } / 1 \\
20,50 \mathrm{~g} \text { sucrose } / 1 \\
1 \cdot 1 \mathrm{~g} \mathrm{AA} / 1+20 \mathrm{~g} \mathrm{~S} / 1 \\
1 \cdot 1 \mathrm{~g} \mathrm{AA} / 1+50 \mathrm{~g} \mathrm{~S} / 1 \\
10.6 \mathrm{~g} \mathrm{AA} / 1+20 \mathrm{~g} \mathrm{~S} / 1 \\
10.6 \mathrm{~g} \mathrm{AA} / 1+50 \mathrm{~g} \mathrm{~S} / 1 \\
18.8 \mathrm{~g} \text { honeydew } / 1\end{array}$ \\
\hline
\end{tabular}

YE, yeast extract; S, sucrose; AA, amino acids; a.i., active ingredient.

\section{Application of treatments and climatic conditions}

The flag leaves of the plants were guided through humidity boxes described by Ubels (1979). Each box contained six leaves, of which three received the same treatment to avoid a differential effect of the boxes. When the leaves in one part of the box were sprayed, other leaves in the box were covered and neighbouring boxes were closed. Suspensions of conidia, nutrients and fungicide were made in triple concentrations and mixed before application. Treatments were applied with a glass reagent sprayer (Desaga) at the upper surface of the leaf until the leaves were covered with a fine mist. The plants were placed in a growth chamber at $18-21^{\circ} \mathrm{C}, 12-15 \mathrm{~h}$ light per day, $85 \%$ r.h. during the light period and $95 \%$ r.h. during the dark period. The humidity boxes were kept closed until the end of the experiment (max. 15 days) to guarantee a constant high humidity, which stimulates infection by $S$. nodorum (Ubels, 1979).

\section{Assessment of percentage germination, germ- tube length and necrotic leaf area}

After 2 days, six leaves per treatment in Experiments 1-6 were used to make leaf imprints on Sellotape which were stained with lactophenol cotton blue $(0 \cdot 1 \%)$. The germ-tube length of 50 spores per leaf was measured with a microscope, drawing tube and semi-automatic image analyser (Morphomat 10, Zeiss). The percentage germinated spores and the average germ-tube length per spore, based on both ungerminated and germinated spores, were calculated for each leaf.

Except for Experiments 1-3, diseased leaf area was assessed on six leaves per treatment after 11 days (Experiments 4 and 5) or 15 days (Experiments 6-9), dependent on disease development. After cutting the leaves at the edges of the box, total area and necrotic leaf area of each leaf were measured with a semi-automatic image analyser (Morphomat 10, Zeiss). The percentage necrotic leaf area (severity) was calculated per leaf and used as a variate representing infection.

\section{Statistical analysis and calculation of antagonism isoboles}

Treatment means were compared only within a fungicide concentration by analysis of variance followed by a $t$-test after logarithmic or arcsine $\sqrt{ } \mathrm{x}$-transformation (Snedecor \& Cochran, 1980).

In addition to comparing treatment means, the data in Experiments 6-9 can be used to calculate antagonistic interaction. Different methods of 
calculating antagonism and synergism have been developed, all for combinations of poisonous chemicals (Levy et al., 1986). The Abbott formula (Abbott, 1925), which has been simplified by Colby (1967), was developed for a combination of herbicides, but it can be adapted for combinations of nutrients and fungicide. The underlying assumption is that the chemicals have independent joint action (Levy et al., 1986). The severities in an experiment are all expressed as a percentage of the severity in the treatment without any additions (control) and the expected effect is calculated according to formula (1) (Colby, 1967):

$$
\quad E_{1 \exp }=\frac{X_{1} \times Y_{1}}{100}
$$

in which $X_{1}$ is the severity as a percentage of control with chemical $\mathrm{A}$ at concentration $x, Y_{1}$ is the severity as a percentage of control with chemical $\mathrm{B}$ at concentration $y$, and $E_{1 \exp }$ is the expected severity as a percentage of control with chemicals $\mathrm{A}+\mathrm{B}$ at concentrations $x+y$. In Experiments 6-9, $X_{1}$ is the effect of the nutrients only and $Y_{1}$ the effect of the fungicide only. $X_{1}$ will then be more than 100 in most cases, but this should not make any difference for the calculation. $E_{1}$ exp is then compared to the observed severity, expressed as percentage of control $\left(E_{\text {lobs }}\right)$. The level of interaction can be expressed in an antagonism factor (in synergy calculations between two fungicides called the synergy factor):

$$
\text { Antagonism factor }(\mathrm{AF})=\frac{E_{\text {lobs }}}{E_{\text {lexp }}} .
$$

If $\mathrm{AF}$ is greater than 1, the nutrients are antagonistic to the fungicide and if AF is smaller than 1 , the nutrients and fungicide are synergistic.

The second commonly used method to calculate interaction is the Wadley formula (Wadley, 1945). This formula is based on dose-response curves and compares $\mathrm{ED}_{50} \mathrm{~s}$, but as it assumes similar joint action of two chemicals and uses $E D_{50}$ s for both chemicals it can not be used for combinations of fungicides and nutrients. However, the design of Experiments 6-9 allows calculation of dose-response curves, comparison of $E D_{50}$-values and the drawing of isoboles (lines of the same effect) as described by Tammes (1964) and De Waard (1985).

In Experiments 6-9 separate fungicide doseresponse curves for each nutrient concentration were calculated as follows. Each severity was expressed as the percentage reduction compared to the severity in the treatment with no fungicide (and the same nutrient level):

$\%$ reduction $=$

$$
100-\left(\frac{\text { severity }}{\text { severity (no fungicide) }} \times 100\right) .
$$

The reduction percentages were probit transformed. Linear regression of these probits against log-transformed fungicide doses yielded doseresponse curves for each nutrient concentration in an experiment (Finney, 1947):

probit $(\%$ reduction $)=$

$$
c+a \times \log \text { (fungicide dose) }
$$

where $c$ is a constant, and $a$ is the slope of the regression line.

Antagonism can then be calculated in two ways, depending on the definition of $E D_{50}$.

1. $\mathrm{ED}_{50(\mathrm{~N})}$ is the fungicide dose needed to obtain $50 \%$ reduction in severity within a certain nutrient concentration, as compared to the fungicide-free treatment at that nutrient level. $\mathrm{ED}_{50(\mathrm{~N})}$ is calculated by entering 50 as percentage reduction in formula (4).

2. $E D_{50 \text { (c) }}$ is the fungicide concentration that reduces the severity to $50 \%$ of that in the treatment without fungicide and without nutrients, as compared to the control. Entering the percentage reduction needed to obtain half of the severity found without nutrients and fungicides in the regression comparisons (formula (4)) gives $\mathrm{ED}_{50}$ (c) values for each nutrient concentration.

Plotting of $E D_{50} / E D_{50}$ no nutrients to nutrient concentrations yields antagonism isoboles. All statistical calculations were done with the statistical software SAS (SAS Institute Inc., 1985).

\section{RESULTS}

\section{Influence of sucrose + yeast extract on the effect of different fungicides}

In Experiments 1-5 the percentage germination was high in all treatments $(80-100 \%)$. The mixture of $20 \mathrm{~g}$ sucrose $/ 1$ and $5 \mathrm{~g}$ yeast extract/1 stimulated germ-tube growth significantly in the presence of the three fungicides propiconazole, fenpropimorph and prochloraz in all concentrations tested (Fig. 1, Table 2). In the case of fenpropimorph and prochloraz this resulted in longer germ tubes than when neither fungicide nor nutrients were added. Increasing the fungi- 

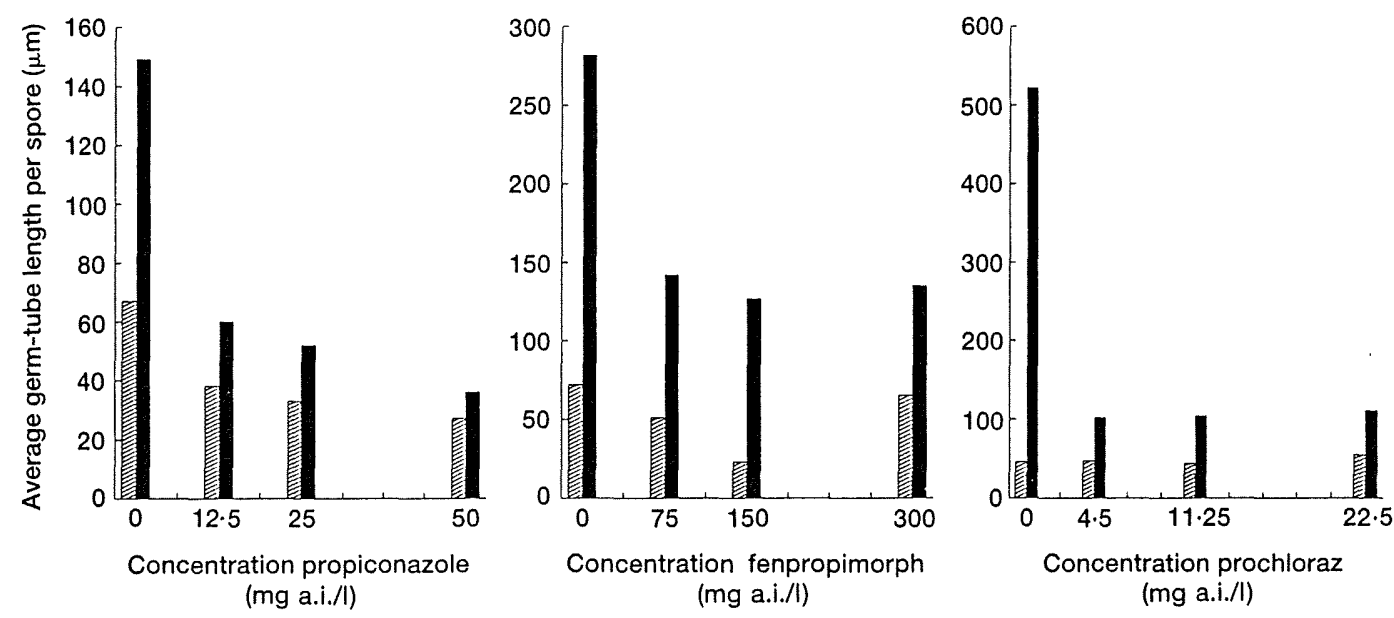

Fig. 1. Influence of $20 \mathrm{~g}$ sucrose $(\mathrm{S}) / \mathrm{l}$ and $5 \mathrm{~g}$ yeast extract $(\mathrm{YE}) / \mathrm{l}$ on inhibition of germ-tube growth by propiconazole, fenpropimorph and prochloraz (Experiments 1-3).

Table 2. Influence of sucrose (S) and yeast extract (YE) on inhibition of germ-tube growth and necrotic leaf area by prochloraz (Experiments $4+5$ ). Standard deviations of mean values are given in parentheses

\begin{tabular}{|c|c|c|c|c|}
\hline \multirow{2}{*}{$\begin{array}{l}\text { Concentration } \\
\text { prochloraz } \\
\text { (mg a.i./l) }\end{array}$} & \multicolumn{2}{|c|}{$\begin{array}{l}\text { Average germ-tube length } \\
\text { per } S . \text { nodorum spore } \\
(\mu \mathrm{m}) \text { on day } 2\end{array}$} & \multicolumn{2}{|c|}{$\begin{array}{l}\text { Percentage necrotic } \\
\text { leaf area on day } 11\end{array}$} \\
\hline & $\begin{array}{c}\text { No } \\
\text { nutrients }\end{array}$ & $\begin{aligned} & 20 \mathrm{~g} \mathrm{~S} / 1 \\
+ & 5 \mathrm{~g} \mathrm{YE} / 1\end{aligned}$ & $\begin{array}{c}\text { No } \\
\text { nutrients }\end{array}$ & $\begin{aligned} & 20 \mathrm{~g} \mathrm{~S} / 1 \\
+ & 5 \mathrm{~g} \mathrm{YE} / 1\end{aligned}$ \\
\hline \multicolumn{5}{|l|}{ Experiment 4} \\
\hline 0 & $76(6 \cdot 3)$ & $358^{*}(39 \cdot 5)$ & $8 \cdot 7(6 \cdot 2)$ & $27 \cdot 9^{*}(11 \cdot 1)$ \\
\hline $22 \cdot 5$ & $35(8 \cdot 5)$ & $105 *(6 \cdot 8)$ & $5 \cdot 1(3 \cdot 9)$ & $11 \cdot 6^{*}(2 \cdot 3)$ \\
\hline $45 \cdot 0$ & $44(10 \cdot 9)$ & $105^{*}(12 \cdot 6)$ & $0.7(0.7)$ & $1 \cdot 3 \quad(1 \cdot 2)$ \\
\hline \multicolumn{5}{|l|}{ Experiment 5} \\
\hline 0 & $68(11 \cdot 2)$ & $367 *(21 \cdot 6)$ & $14.4(7 \cdot 5)$ & $80 \cdot 8^{*}(30 \cdot 3)$ \\
\hline $45 \cdot 0$ & $32(4 \cdot 8)$ & $97 *(8 \cdot 2)$ & $0.4(0.4)$ & $6 \cdot 7^{*}(4 \cdot 9)$ \\
\hline $135 \cdot 0$ & $48(8 \cdot 8)$ & $81 *(8 \cdot 6)$ & $0.0(0.0)$ & $1 \cdot 0 *(0 \cdot 5)$ \\
\hline
\end{tabular}

* Significantly different at $P=0.05$ from treatment without nutrients and the same fungicide concentration.

cide dose did not increase inhibition of germ-tube growth in these experiments. The number of branches per germ tube increased linearly with the average germ-tube length per spore $\left(r^{2}=0 \cdot 99\right.$ data not shown).

The sucrose/yeast extract mixture also gave significant $(P=0 \cdot 05)$ stimulation of diseased leaf area at different prochloraz concentrations (Table 2), although at higher fungicide concentrations there was a strong reduction of diseased leaf area.
Influence of composition and concentration of nutrients on infection in the presence of prochloraz

Application of nutrients without $S$. nodorum spores did not cause yellowing or necrosis of leaves in any of the experiments.

In Experiment 6 different sucrose concentrations, combined with yeast extract $(5 \mathrm{~g} / 1)$, all demonstrated approximately the same stimulation of germ-tube length (Table 3). This stimu- 
Table 3. Influence of sucrose concentration in combination with yeast extract on inhibition of germ-tube growth by prochloraz (Experiment 6). Standard deviations of mean values are given in parentheses

\begin{tabular}{|c|c|c|c|c|c|c|}
\hline \multirow{2}{*}{$\begin{array}{l}\text { Concentration } \\
\text { prochloraz } \\
(\mathrm{mg} \text { a.i./l) }\end{array}$} & \multicolumn{6}{|c|}{ Average germ-tube length per spore $(\mu \mathrm{m})$, day 2} \\
\hline & $\begin{array}{c}\text { No } \\
\text { nutrients }\end{array}$ & $\begin{aligned} & 10 \mathrm{~g} \mathrm{~S} / 1 \\
+ & 5 \mathrm{~g} \mathrm{YE} / 1\end{aligned}$ & $\begin{array}{c}20 \mathrm{~g} \mathrm{~S} / 1 \\
+5 \mathrm{~g} \mathrm{YE} / 1\end{array}$ & $\begin{array}{c}50 \mathrm{~g} \mathrm{~S} / 1 \\
+5 \mathrm{~g} \mathrm{YE} / 1\end{array}$ & $\begin{array}{c}100 \mathrm{~g} \mathrm{~S} / 1 \\
+5 \mathrm{~g} \mathrm{YE} / 1\end{array}$ & $\begin{array}{c}150 \mathrm{~g} \mathrm{~S} / 1 \\
+5 \mathrm{~g} \mathrm{YE} / 1\end{array}$ \\
\hline 0.0 & $31 \cdot 1(5 \cdot 7)$ & $76 \cdot 5^{*}(15 \cdot 9)$ & $82 \cdot 3^{*}(23 \cdot 9)$ & $103 \cdot 4 *(28 \cdot 8)$ & $94 \cdot 4 *(49 \cdot 3)$ & $113 \cdot 4 *(24 \cdot 5)$ \\
\hline $11 \cdot 3$ & $29 \cdot 2(9 \cdot 0)$ & $61 \cdot 0 *(10 \cdot 3)$ & $59 \cdot 7^{*}(4 \cdot 6)$ & $63 \cdot 2 *(14 \cdot 7)$ & $70 \cdot 4 *(11 \cdot 6)$ & $56 \cdot 3 *(4 \cdot 7)$ \\
\hline $22 \cdot 5$ & $25 \cdot 1(8 \cdot 2)$ & $50.7 *(11.9)$ & $52 \cdot 9 *(6 \cdot 3)$ & $51 \cdot 9 *(4 \cdot 1)$ & $50 \cdot 5^{*}(9 \cdot 1)$ & $51 \cdot 7 *(5 \cdot 9)$ \\
\hline $45 \cdot 0$ & $26.5(5.9)$ & ND & $49 \cdot 3 *(17 \cdot 0)$ & ND & ND & ND \\
\hline
\end{tabular}

S, sucrose; YE, yeast extract; ND, not determined.

* Significantly different at $P=0.05$ from treatment without nutrients and the same fungicide concentration.

Table 4. Influence of sucrose concentration in combination with yeast extract on inhibition of disease development by prochloraz (Experiment 6). Standard deviations of mean values are given in parentheses

\begin{tabular}{|c|c|c|c|c|c|c|}
\hline \multirow{2}{*}{$\begin{array}{l}\text { Concentration } \\
\text { prochloraz } \\
\text { (mg a.i./l) }\end{array}$} & \multicolumn{6}{|c|}{ Percentage necrotic leaf area, day 15} \\
\hline & $\begin{array}{c}\text { No } \\
\text { nutrients }\end{array}$ & $\begin{array}{c}10 \mathrm{~g} \mathrm{~S} / 1 \\
+5 \mathrm{~g} \mathrm{YE} / 1\end{array}$ & $\begin{aligned} & 20 \mathrm{~g} \mathrm{~S} / 1 \\
+ & 5 \mathrm{~g} \mathrm{YE} / 1\end{aligned}$ & $\begin{array}{c}50 \mathrm{~g} \mathrm{~S} / 1 \\
+5 \mathrm{~g} \mathrm{YE} / 1\end{array}$ & $\begin{array}{l}100 \mathrm{~g} \mathrm{~S} / 1 \\
+5 \mathrm{~g} \mathrm{YE} / 1\end{array}$ & $\begin{aligned} & 150 \mathrm{~g} \mathrm{~S} / 1 \\
+ & 5 \mathrm{~g} \mathrm{YE} / 1\end{aligned}$ \\
\hline $0 \cdot 0$ & $6 \cdot 3(2 \cdot 9)$ & $89 \cdot 7^{*}(10 \cdot 5)$ & $90 \cdot 0^{*}(5 \cdot 2)$ & $92 \cdot 7 *(4 \cdot 5)$ & $90 \cdot 9 *(8 \cdot 7)$ & $75 \cdot 6^{*}(22 \cdot 8)$ \\
\hline $4 \cdot 5$ & $5 \cdot 2(4 \cdot 1)$ & $45 \cdot 4^{*}(21 \cdot 6)$ & $22 \cdot 2(12 \cdot 9)$ & $37 \cdot 3 *(28 \cdot 0)$ & $26 \cdot 3 *(11 \cdot 5)$ & $28 \cdot 6^{*}(9 \cdot 1)$ \\
\hline $11 \cdot 3$ & $1.5(0.6)$ & $1 \cdot 7 \quad(1 \cdot 3)$ & $11 \cdot 4 *(10 \cdot 3)$ & $11 \cdot 2 *(9 \cdot 6)$ & $19 \cdot 5 *(8 \cdot 6)$ & $9 \cdot 3 *(6 \cdot 6)$ \\
\hline $22 \cdot 5$ & $1 \cdot 0(1 \cdot 5)$ & $3 \cdot 2 \quad(4 \cdot 2)$ & $4 \cdot 1(2 \cdot 3)$ & $7 \cdot 8 *(6 \cdot 6)$ & $6.6 \quad(5 \cdot 2)$ & $9 \cdot 9 *(11 \cdot 5)$ \\
\hline $45 \cdot 0$ & $0.4(0.8)$ & $5.6 \quad(6.0)$ & $1.9(2 \cdot 6)$ & $3 \cdot 6 \quad(3 \cdot 9)$ & $3 \cdot 5(5 \cdot 1)$ & $29 \cdot 2 *(34 \cdot 4)$ \\
\hline 135 & $0.5(0.5)$ & ND & $1 \cdot 3(0 \cdot 5)$ & $2 \cdot 5 *(2 \cdot 2)$ & $1.4(1 \cdot 1)$ & $2 \cdot 1 *(1 \cdot 3)$ \\
\hline 225 & $0.0(0.0)$ & $\mathrm{ND}$ & $0.5(0.2)$ & $1.0 \quad(0.7)$ & $0.6 \quad(0.3)$ & $15 \cdot 5^{*}(11 \cdot 4)$ \\
\hline$r^{2}$ & 0.81 & 0.43 & 0.96 & 0.92 & 0.98 & $0 \cdot 17$ \\
\hline $\mathrm{ED}_{50(\mathrm{~N})}$ & $8 \cdot 8$ & $1 \cdot 8$ & 0.8 & $1 \cdot 4$ & 1.6 & 0.1 \\
\hline $\mathrm{ED}_{50(\mathrm{c})}$ & $8 \cdot 8$ & $31 \cdot 4$ & $42 \cdot 8$ & 74.5 & $59 \cdot 6$ & 3450 \\
\hline
\end{tabular}

$\mathrm{S}$, sucrose; YE, yeast extract; ND, not determined.

* Significantly different at $P=0.05$ from treatment without nutrients and the same fungicide concentration.

$r^{2}$, coefficient of determination of dose-response curves.

$\mathrm{ED}_{50(\mathrm{~N})}, \mathrm{ED}_{50(\mathrm{c})}$, see text.

lation occurred both in the absence and presence of fungicide.

All sucrose concentrations in Experiment 6 gave strong stimulation of necrotic leaf area in the treatments without fungicide. With increasing fungicide concentrations generally more sucrose was needed to obtain significant stimulation compared to the treatment without nutrients (Table 4).

The mixture of amino acids did not significantly stimulate germination and germ-tube growth either with or without fungicide (data not shown). In Experiment 7 there was no significant stimulation of necrotic leaf area by the aminoacid mixture in the fungicide-free treatments, but there was stimulation in combination with some prochloraz concentrations (Table 5). In the same experiment aphid honeydew stimulated necrosis both in the treatments with and without fungicide, especially at the higher honeydew concentrations. Again, as in Experiment 6, at higher fungicide concentrations more honeydew was needed to increase severity significantly.

When only sucrose was supplied (Experiment 8 ) in concentrations of $20 \mathrm{~g} / \mathrm{l}$ or more, stimulation of disease development occurred both with and 
Table 5. Influence of amino-acid concentration and honeydew concentration on inhibition of disease development by prochloraz (Experiment 7). Standard deviations of mean values are given in parentheses

\begin{tabular}{|c|c|c|c|c|c|c|c|}
\hline \multirow[b]{2}{*}{$\begin{array}{l}\text { Concentration } \\
\text { prochloraz } \\
\text { (mg a.i./l) }\end{array}$} & \multicolumn{7}{|c|}{ Percentage necrotic leaf area, day 15} \\
\hline & $\begin{array}{c}\text { No } \\
\text { nutrients }\end{array}$ & $\begin{array}{c}\mathrm{l} \cdot \mathrm{I} \mathrm{g} \\
\text { amino } \\
\text { acids/l }\end{array}$ & $\begin{array}{c}3 \cdot 2 \mathrm{~g} \\
\text { amino } \\
\text { acids } / 1\end{array}$ & $\begin{array}{l}10.6 \mathrm{~g} \\
\text { amino } \\
\text { acids/1 }\end{array}$ & $\begin{array}{c}8.5 \mathrm{~g} \\
\text { honeydew } / 1\end{array}$ & $\begin{array}{c}19 \cdot 0 \mathrm{~g} \\
\text { honeydew } / 1\end{array}$ & $\begin{array}{c}47.0 \mathrm{~g} \\
\text { honeydew } / 1\end{array}$ \\
\hline $0 \cdot 0$ & $40 \cdot 3(29 \cdot 1)$ & $42 \cdot 9(24 \cdot 1)$ & $48 \cdot 5(40 \cdot 6)$ & $64.9 \quad(27 \cdot 6)$ & $64 \cdot 2(26 \cdot 1)$ & $75 \cdot 3 *(21 \cdot 1)$ & $76.9 *(14.9)$ \\
\hline $4 \cdot 5$ & $24 \cdot 5(12 \cdot 8)$ & $44 \cdot 0(18 \cdot 3)$ & $24 \cdot 0 \quad(15 \cdot 3)$ & $46 \cdot 4 \quad(5 \cdot 3)$ & $51 \cdot 3 *(23 \cdot 5)$ & $37 \cdot 7 \quad(17 \cdot 0)$ & $80 \cdot 3 *(16 \cdot 8)$ \\
\hline $11 \cdot 3$ & $14 \cdot 0(8 \cdot 7)$ & $20 \cdot 1(20 \cdot 1)$ & $30 \cdot 6 \quad(35 \cdot 3)$ & $44.4 *(23.9)$ & $22 \cdot 8 \quad(21 \cdot 8)$ & $16 \cdot 1 \quad(13 \cdot 0)$ & $52 \cdot 1 *(20 \cdot 2)$ \\
\hline $22 \cdot 5$ & $8.9(8 \cdot 7)$ & $9 \cdot 7(13 \cdot 7)$ & $28 \cdot 5 *(20 \cdot 3)$ & $39 \cdot 3 *(21 \cdot 8)$ & $10 \cdot 0(7 \cdot 7)$ & $8 \cdot 3 \quad(4 \cdot 3)$ & $45 \cdot 6 *(21 \cdot 5)$ \\
\hline $45 \cdot 0$ & $6 \cdot 5(4 \cdot 6)$ & $4 \cdot 6(1 \cdot 7)$ & $19 \cdot 1 *(26 \cdot 3)$ & $12 \cdot 8 \quad(15 \cdot 8)$ & ND & $12.9(10 \cdot 9)$ & $7 \cdot 6 \quad(2 \cdot 4)$ \\
\hline$r^{2}$ & 0.97 & 0.99 & $0 \cdot 13$ & $0 \cdot 72$ & 0.99 & $0 \cdot 70$ & 0.85 \\
\hline $\mathrm{ED}_{50(\mathrm{~N})}$ & $6 \cdot 5$ & $9 \cdot 9$ & $30 \cdot 2$ & $18 \cdot 5$ & 8.9 & $2 \cdot 9$ & $19 \cdot 3$ \\
\hline $\mathrm{ED}_{50(\mathrm{c})}$ & 6.5 & $10 \cdot 8$ & $264 \cdot 4$ & $44 \cdot 1$ & $13 \cdot 6$ & $11 \cdot 5$ & $31 \cdot 9$ \\
\hline
\end{tabular}

ND, not determined.

* Significantly different at $P=0.05$ from treatment without nutrients and the same fungicide concentration. $r^{2}$, coefficient of determination of dose-response curves. $\mathrm{ED}_{50(\mathrm{~N})}, \mathrm{ED}_{50(\mathrm{c})}$, see text.

without fungicide, whereas in the concentration of $10 \mathrm{~g} / 1$ there was no significant stimulation (Table 6). In this experiment aphid honeydew caused somewhat stronger stimulation than sucrose alone (Table 6).

The effect of two amino acid concentrations and two sucrose concentrations separately and combined and the effect of aphid honeydew was compared in Experiment 9 (Table 7). In the mixture of $1.1 \mathrm{~g}$ amino acids/l and $50 \mathrm{~g}$ sucrose $/ 1$ the ratio between amino acids and carbohydrates was the same as in the honeydew analysed by Rossing \& Van de Wiel (1990). The effect of amino acids on infection in Experiment 9 was similar to the effect found in Experiment 7. The effect of sucrose alone, however, was smaller than that in Experiment 8. Adding sucrose to the lowest amino acid concentration gave additional stimulation of infection, which did not seem to be dependent on sucrose concentration. At the higher amino acid level addition of sucrose only in some treatments further stimulated infection. When the treatments with $20 \mathrm{~g}$ sucrose/l are compared to those with $20 \mathrm{~g}$ sucrose/ 1 plus different concentrations of amino acids, the Septoria infection was further stimulated by the addition of amino acids, especially in the highest concentration. Adding amino acids to $50 \mathrm{~g}$ sucrose $/ 1$ also increased disease intensity. In this experiment the effect of aphid honeydew was stronger than that of only sucrose at approximately the same con- centration $(20 \mathrm{~g} / 1)$ and comparable to the effect of this sucrose concentration in combination with amino acids (Table 7).

\section{Interaction between nutrients and fungicide effectiveness}

Calculation of interaction according to Colby (1967) resulted in antagonism factor (AF) values smaller than 1 in Experiment 6, suggesting synergism. In Experiments 7-9 the AF values were larger than 1 in almost all combinations of nutrients and fungicide, so in these experiments the nutrients were antagonistic to prochloraz. AF values for aphid honeydew in Experiments 7-9 are shown in Table 8.

The $E_{50}$ for prochloraz against disease development of $S$. nodorum in the absence of nutrients ranged from $2 \cdot 2$ to $8.8 \mathrm{mg}$ a.i./l. Most dose-response curves have high coefficients of determination $\left(r^{2}\right)$. Values of $r^{2}, \mathrm{ED}_{50}(\mathrm{~N})$ and $E_{50(c)}$ are given in Tables 4-7. The values of the $\mathrm{ED}_{50(\mathrm{~N})}$ were lower in Experiment 6 and higher in Experiments 7-9 in the presence of nutrients compared with the treatment without nutrients. The $E_{50 \text { (c) }}$ was higher in all experiments in the presence of nutrients. The indication for synergism in Experiment 6, which was found in both the Colby method and in comparing $\mathrm{ED}_{50(\mathrm{~N})}$, is probably due to the very large stimulation of severity by the nutrients in the fungicide-free 


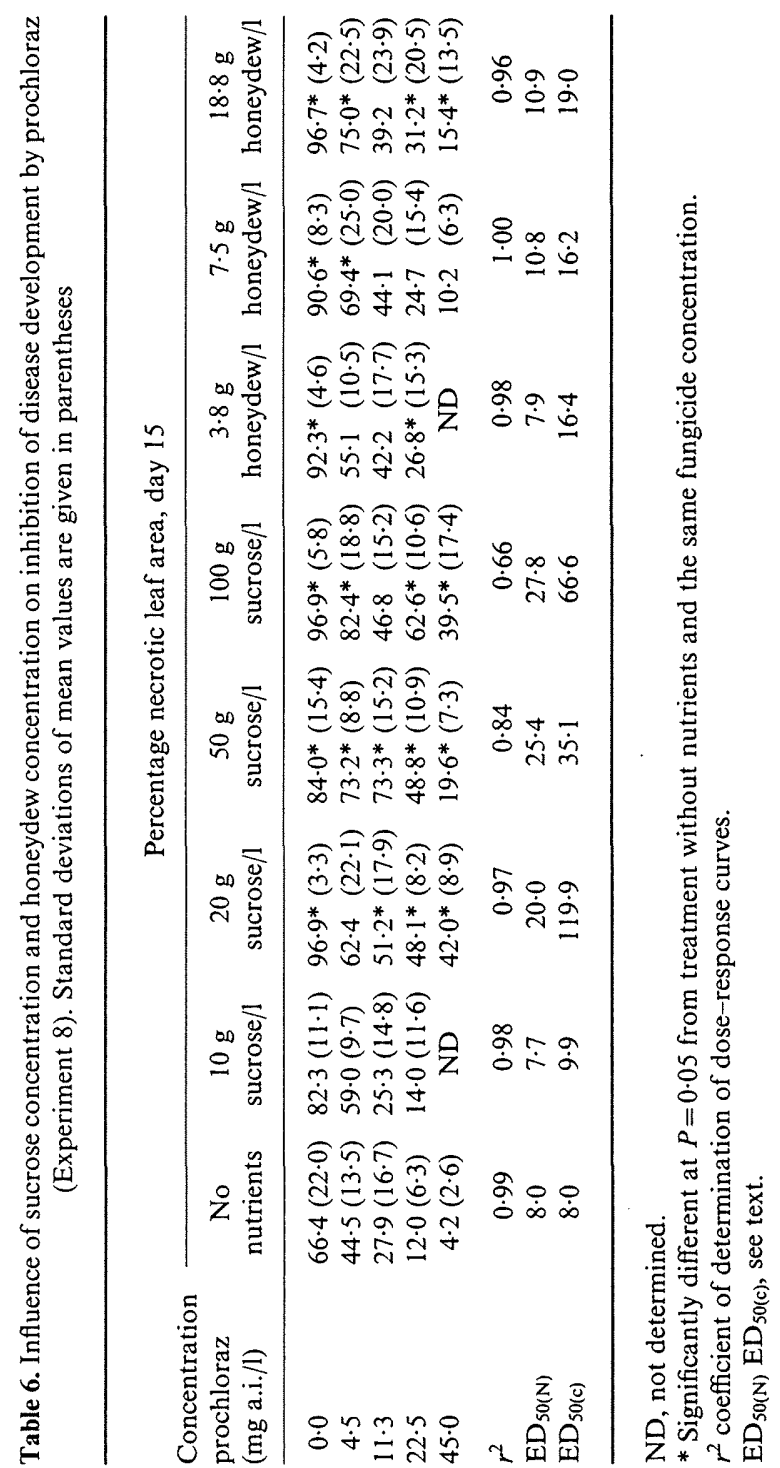




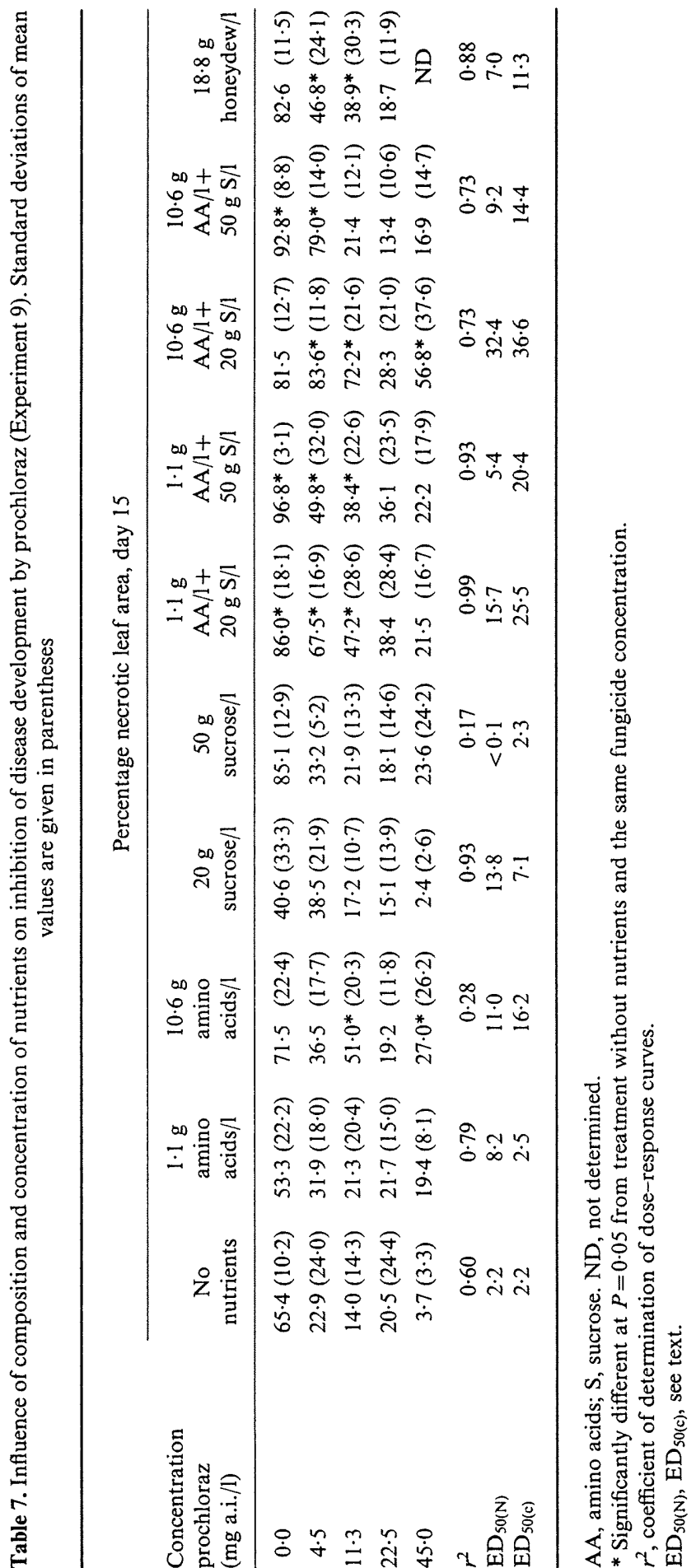


Table 8. Antagonism factor ( $E_{1 \text { obs }} / E_{l}$ exp ) for aphid honeydew, calculated according to the Colby method

\begin{tabular}{|c|c|c|c|c|c|c|c|}
\hline \multirow[b]{2}{*}{$\begin{array}{l}\text { Concentration prochloraz } \\
(\mathrm{mg} \text { a.i. } / \mathrm{l})\end{array}$} & \multicolumn{3}{|c|}{ Experiment 7} & \multicolumn{3}{|c|}{ Experiment 8} & \multirow{2}{*}{ 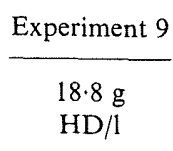 } \\
\hline & $\begin{array}{l}8.5 \mathrm{~g} \\
\mathrm{HD} / 1\end{array}$ & $\begin{array}{l}19 \cdot 0 \mathrm{~g} \\
\mathrm{HD} / 1\end{array}$ & $\begin{array}{l}47.0 \mathrm{~g} \\
\mathrm{HD} / 1\end{array}$ & $\begin{array}{l}3 \cdot 8 \mathrm{~g} \\
\mathrm{HD} / 1\end{array}$ & $\begin{array}{l}7.5 \mathrm{~g} \\
\mathrm{HD} / 1\end{array}$ & $\begin{array}{l}18 \cdot 8 \mathrm{~g} \\
\mathrm{HD} / 1\end{array}$ & \\
\hline $4 \cdot 5$ & $1 \cdot 3$ & 0.8 & $1 \cdot 7$ & 0.9 & $1 \cdot 1$ & $1 \cdot 2$ & 1.6 \\
\hline $11 \cdot 3$ & $2 \cdot 9$ & $2 \cdot 9$ & $2 \cdot 9$ & $1 \cdot 1$ & $1 \cdot 2$ & $1 \cdot 0$ & $2 \cdot 2$ \\
\hline $22 \cdot 5$ & 0.7 & 0.5 & $2 \cdot 7$ & 1.6 & 1.5 & 1.8 & 0.7 \\
\hline $45 \cdot 0$ & ND & $1 \cdot 1$ & $0 \cdot 6$ & ND & 1.8 & $2 \cdot 5$ & ND \\
\hline
\end{tabular}

ND, not determined; HD, aphid honeydew.

treatments. The net effect of combinations of -nutrients with fungicide however, indicated by $E D_{50(c)}$, is antagonistic in all experiments.

Antagonism isoboles of $E D_{50 \text { (c) }}$ for different nutrients are shown in Fig. 2. Only data from dose-response curves with coefficients of determination higher than 0.70 were used. Contrary to De Waard (1985) and Tammes (1964) nutrient concentrations are on the abscissa and relative $\mathrm{ED}_{50} \mathrm{~s}$ on the ordinate. The isoboles show that $\mathrm{ED}_{50} \mathrm{~S}$ increase up to ten times with increasing nutrient concentrations.

\section{DISCUSSION}

Aphid honeydew and its components sucrose and amino acids can stimulate infection of wheat leaves by $S$. nodorum in the presence of the fungicide prochloraz. This effect on infection could not be adequately estimated by assessing percentage germination and germ-tube length. Stimulation of germ-tube growth is accompanied by stimulation of necrosis, but the converse is not necessarily true. Amino acids, for example, do not stimulate germ-tube growth but can enhance necrosis in the presence of prochloraz. Furthermore, ergosterol biosynthesis-inhibiting fungicides generally have little effect on germination and germ-tube growth (Siegel, 1981), so the effect of these fungicides and antagonism against them can best be studied in in-vivo experiments, measuring infection.

Infection by $S$. nodorum is strongly stimulated by sucrose combined with yeast extract, whereas the effect of sucrose alone is variable. Fokkema $e t$ al. (1983) also found that stimulation of necrosis by Cochliobolus sativus was smaller in the presence of sucrose than in the presence of sucrose + yeast extract or aphid honeydew.
The influence of the mixture of amino acids on severity is similar in Experiments 7 and 9. A synergistic effect of some of the amino acids that were used has been reported, but in a mixture this effect can be nullified by the antagonistic effect of the other amino acids (Chopra \& Jhooty, 1974). Cirrhus extract of $S$. nodorum also contains a mixture of amino acids (Rapilly \& Skajennikoff, 1974) and might also stimulate infection of $S$. nodorum in the presence of fungicides.

Aphid honeydew stimulated infection more strongly than its components sucrose and amino acids separately. In the analysis of the antagonism caused by leaf exudates similar results were reported by Beynon \& Brown (1969), who found that the compounds glucose and fructose in the exudates were the most important antagonistic factor but that the effect could not be completely stimulated by these carbohydrates alone.

The stimulation of infection by all nutrient sources is generally larger when the ratio of nutrients/fungicide is larger, but because of the differences in severity between experiments in the treatment without fungicide and without nutrients, it is not possible to estimate severity as a function of nutrient concentration and fungicide concentration. Due to large variation of the necrotic leaf area within the treatments in an experiment, differences between percentages of diseased leaf area are not always significant at the $5 \%$ level. However, in accordance with Finney (1947), increasing the number of replicates to reduce variation at the expense of the number of treatments was rejected, because it would have decreased the number of values on which dose-response curves are based.

The method described of calculating doseresponse curves generally gives high coefficients of determination. Both methods of calculating 

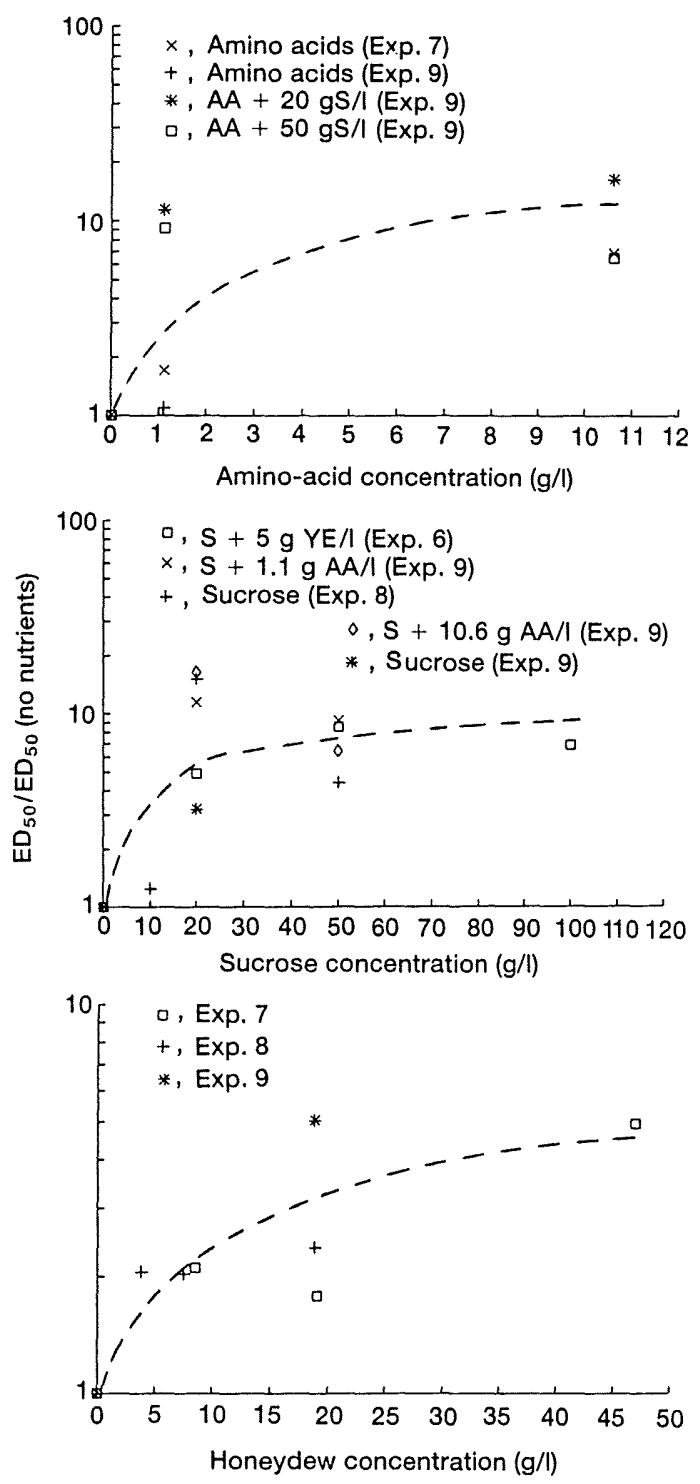

Fig. 2. Antagonism isoboles for amino acids (AA), sucrose (S) and aphid honeydew against prochloraz.

$\mathrm{ED}_{50} \mathrm{~s}$ indicate antagonism in Experiments 7-9, but in Experiment 6 the results seem contradictory. The $\mathrm{ED}_{50}(\mathrm{~N})$ gives information about the behaviour of a fungicide at a certain nutrient level, whereas the $E D_{50(c)}$ gives information about the net effect of the combined presence of nutrients and fungicide. In synergy calculations the $\mathrm{ED}_{50}$ is usually defined as the dose that reduces severity to $50 \%$ of that in the treatment without any additions, which is the same as the
$\mathrm{ED}_{\mathrm{s}^{(c)}}$ in this report. Dunn et al. (1971) calculated the effect of exudates on $E D_{50}$ by measuring percentage germination, but as there was close to $100 \%$ germination in the treatment without fungicide and without exudates, the exudates could not strongly stimulate germination in the fungicide-free treatment and therefore $\mathrm{ED}_{50}(\mathrm{~N})$ and $E_{50}(c)$ are approximately the same. Antagonism calculations between a stimulating and a toxic component have to our knowledge not yet been described for experiments in which infection was measured. In our opinion, using the $\mathrm{ED}_{50 \text { (c) }}$ in the calculations is preferable, because the net effect is most important. Using the $\mathrm{ED}_{s 0}$ $(\mathrm{N})$, however, can give additional information about the way the net effect is reached. Comparison of $\mathrm{ED}_{50}$ is preferred to the Colby method (Colby, 1967), because that method does not allow for generalization of the effect of a certain nutrient concentration on fungicide effectiveness, but only gives information about single combinations of nutrients and fungicide. The Colby method, however, can be used when the number of treatments is too small for calculation of doseresponse curves. It can be concluded from the antagonism calculations that aphid honeydew and its main components are antagonistic to the fungicide prochloraz and that this effect is partly the result of an additional effect of stimulation and inhibition, partly caused by detoxification of the fungicide.

Antagonism against fungicides can be based on a physico-chemical interaction with the fungicide outside the pathogen or on a physiological interaction with the metabolism of the pathogen (De Waard, 1985). In the work presented here, chemical interaction outside the pathogen does not seem very likely, because the antagonism was found with different kinds of nutrients and sucrose + yeast extract also showed an antagonistic effect on other kinds of fungicides (Dik \& Fokkema, 1988). Control experiments, in which nutrients were left on leaves for 3 days and then washed off before the pathogen was applied, did not show stimulation of either germ-tube growth or diseased-leaf area of $S$. nodorum, so it also seems unlikely that the effect is caused by a change in the physiology of the plants (A. J. Dik, unpublished data). In our opinion the antagonistic effect is caused by stimulation of the metabolism of the pathogen. The carbohydrates might cause an increase of the energy-dependent efflux of the fungicide, while the amino acids might stimulate the production of detoxifying enzymes.

The antagonistic effect of aphid honeydew on 
fungicide activity still has to be demonstrated in field experiments. It might very well be of practical importance, because in wheat crops aphids and therefore honeydew are normally present from May to August. Furthermore, the antagonistic effect of nutrients on fungicide activity was also found when $C$. sativus was used as a test pathogen (Dik \& Fokkema, 1988). Because of the non-specificity of the effect, it seems highly likely that other necrotrophic pathogens, e.g. Septoria tritici, will be stimulated by honeydew in the same way. There is probably little effect on biotrophic pathogens such as rusts and mildew, because these fungi do not use nutrients from the leaf surface before penetration. Although the fungicide concentrations used in the experiments are much lower than spraying concentrations in the field, the actual fungicide concentration on fieldgrown wheat leaves can be approximately the same because the concentration decreases steadily after spraying due to, for example, washing-off by rain. Most selective fungicides are sprayed only once, so there is no repeated increase in fungicide concentration.

Possibly other nutrient sources in the phyllosphere beside aphid honeydew, such as pollen, leaf exudates and cirrhus extract, also reduce fungicide activity. Pollen, for example, stimulates infection of $S$. nodorum and $C$. sativus (Fokkema, 1971) and might well be also antagonistic to fungicides. However, the naturally occurring microflora on wheat leaves, consisting mainly of . yeasts, can use both pollen and honeydew as a nutrient source. It has been demonstrated that, in a controlled environment, yeasts can effectively remove nutrients from wheat leaves (Fokkema et al., 1983). In wheat fields, however, the naturally occurring microflora is often reduced by nonselective fungicides. In such cases, aphid honeydew and pollen can accumulate on the leaves. Removal of aphid honeydew by yeasts has been demonstrated under field conditions and will be described elsewhere (A. J. Dik, unpublished data). This can imply that leaving the naturally occurring microflora intact by using only selective fungicides can prevent the antagonistic effect of aphid honeydew and other nutrients on fungicide activity. In this light the often-applied combination of EBI-fungicides with broad-spectrum fungicides is not to be recommended.

\section{ACKNOWLEDGEMENTS}

The investigations were supported by the Foundation for Fundamental Biological Research
(BION), which is subsidized by the Netherlands organization for scientific research (NWO). The authors wish to thank Dr M. A. de Waard for critical discussions and professors B. Schippers and $\mathrm{R}$. Rabbinge for reviewing the manuscript. Thanks are also expressed to the Research Institute for Plant Protection in Wageningen for lending the humidity boxes and to Thea van Beers for practical assistance.

\section{REFERENCES}

Abbott W.S. (1925) A method of computing the effectiveness of an insecticide. Journal of Economic Entomology 18, 265-267.

Beynon K.I. \& Brown K.F. (1969) The identification of a fungicide antagonist in leaf exudate. Phytopathologische Zeitschrift 64, 213-220.

Chopra B.L. \& Jhooty J.S. (1974) Antagonism between zineb and water soluble leachates of spores of Alternaria cucumerina. Indian Phytopathology 27, 209-214.

Colby S.R. (1967) Calculating synergistic and antagonistic responses of herbicide combinations. Weeds 15 , 20-22.

De Waard M.A. (1985) Fungicide synergism and antagonism. In: Fungicides for Crop Protection. $B C P C$ Monograph 31, 89-95. BCPC, Croydon.

Dik A.J. \& N.J. Fokkema (1988) Reduced effect of fungicides on perthotrophic pathogens on wheat in the presence of nutrients. Acta Botanica Neerlandica $37,542-543$.

Dunn C.L., Beynon K.F. \& Montagne J.Th.W. (1971) The effect of glucose in leaf exudates upon the biological activity of some fungicides. In: Ecology of Leaf Surface Micro-organisms (Ed. by T. F. Preece \& C. H. Dickinson), pp. 491-507. Academic Press, London.

Dunn C.L., Brown K.F. \& Montagne J.Th.W. (1969) Antagonism between fungicides and water soluble exudates from the leaves of plants. Phytopathologische Zeitschrift 64, 112-118.

Finney D.J. (1947) Probit Analysis. Cambridge University Press, Cambridge.

Fokkema N.J. (1971) The effect of pollen in the phyllosphere of rye on colonization by saprophytic fungi and on infection by Helminthosporium sativum and other leaf pathogens. Netherlands Journal of Plant Pathology, 77 (Suppl. 1), 1-60.

Fokkema N.J., Riphagen I., Poot R.J. \& De Jong C. (1983) Aphid honeydew, a potential stimulant of Cochliobolus sativus and Septoria nodorum and the competitive role of saprophytic mycoflora. Transactions of the British Mycological Society 81, 355-363.

Grover R.K., Batra G.K. \& Jhooty J.S. (1969) Modification of toxicity of cycloheximide and dodine to Cladosporium fulvum by tomato leaf exudates. Phytopathologische Zeitschrift 64, 355-361. 
Grover R.K. \& Kumar M. (1965) Effect of carbohydrates on the toxicity of cycloheximide against Pythium aphanidermatum. Indian Journal of Microbiology 5, 25-32.

Hewitt B.R. (1958) Spectrophotometric determination of total carbohydrate. Nature 182, 246-247.

Jhooty J.S. \& Bains S.S. (1976) Modification of toxicity of benomyl by seed exudates of mung. Indian Journal of Microbiology 16, 73-75.

Kataria H.R. \& Grover R.K. (1976) Some factors affecting the control of Rhizoctonia solani by systemic and non-systemic fungicides. Annals of Applied Bio$\log y$ 82, 267-278.

Kataria H.R. \& Grover R.K. (1978) Reversal of toxicity of some systemic and non-systemic fungitoxicants by chemicals. Zeitschrift für Pflanzenkrankheiten und Pflanzenschutz 85, 76-83.

Levy Y., Benderly M., Cohen Y., Gisi U. \& Bassand D. (1986) The joint action of fungicides in mixtures: comparison of two methods for synergy calculation. EPPO Bulletin 16, 651-657.

Rabbinge R., Brouwer A., Fokkema N.J., Sinke J. \& Stomph T.J. (1984) Effects of the saprophytic leaf microflora on growth and productivity of winter wheat. Netherlands Journal of Plant Pathology 90, $181-197$.

Rapilly F. \& Skajennikoff M. (1974) Etudes sur l'inoculum de Septoria nodorum Berk. agent de la septoriose du blé. Annales de Phytopathologie 6, 71-82.

Richardson L.T. (1966) Reversal of fungitoxicity of thiram by seed and root exudates. Canadian Journal of Botany 44, 111-113.
Rossing W.A.H. \& Van de Wiel L.A.J.M. (1990) Simulation of damage in winter wheat caused by the grain aphid Sitobion avenae. I. Quantification of the effects of honeydew on gas exchange of leaves and aphid populations of different size on crop growth. Netherlands Journal of Plant Pathology 96, 343-364.

SAS Institute Inc. (1985) SAS User's Guide: Basics, Version 5 Edition. SAS Institute Inc., Cary, NC. 1290 pp.

SAS Institute Inc. (1985) Statistics, Version 5 Edition. SAS Institute Inc. Cary, NC. 956 pp.

Siegel M.R. (1981) Sterol-inhibiting fungicides: effects on sterol biosynthesis and sites of action. Plant Disease 65, 986-989.

Snedecor G.W. \& Cochran W.G. (1980) Statistical Methods. Iowa State University Press, Ames, Iowa.

Tammes P.M.L. (1964) Isoboles, a graphic presentation of synergism in pesticides. Netherlands Journal of Plant Pathology 70, 73-80.

Ubels E. (1979) A method to test wheat leaves for their reactions to inoculation with Septoria species. Netherlands Journal of Plant Pathology 85, 143-150.

Wadley, F.M. (1945) The Evidence Required to Show Synergistic Action of Insecticides and a Short Cut in Analysis. US Department of Agriculture, Bureau of Entomology and Plant Quarantaine No. ET-223.

Zadoks J.C., Chang T.T. \& Konzak C.F. (1974) A decimal code for the growth stages of cereals. Weed Research 14, 415-421. 